\title{
Selective Deletion of the Internal Lysine Residue from the Peptide Sequence by Collisional Activation
}

\author{
Shibdas Banerjee, Shyamalava Mazumdar
}

Department of Chemical Sciences, Tata Institute of Fundamental Research, Mumbai 400005, India

\begin{abstract}
The gas-phase peptide ion fragmentation chemistry is always the center of attraction in proteomics to analyze the amino acid sequence of peptides and proteins. In this work, we describe the formation of an anomalous fragment ion, which corresponds to the selective deletion of the internal lysine residue from a series of lysine containing peptides upon collisional activation in the ion trap. We detected several water-loss fragment ions and the maximum number of water molecules lost from a particular fragment ion was equal to the number of lysine residues in that fragment. As a consequence of this water-loss phenomenon, internal lysine residues were found to be deleted from the peptide ion. The $\mathrm{N}, \mathrm{N}$-dimethylation of all the amine functional groups of the peptide stopped the internal lysine deletion reaction, but selective $\mathrm{N}$ terminal $\alpha$-amino acetylation had no effect on this process indicating involvement of the side chains of the lysine residues. The detailed mechanism of the lysine deletion was investigated by multistage CID of the modified and unmodified peptides, by isotope labeling and by energy resolved CID studies. The results suggest that the lysine deletion might occur through a unimolecular multistep mechanism involving a seven-membered cyclic imine intermediate formed by the loss of water from a lysine residue in the protonated peptide. This intermediate subsequently undergoes degradation reaction to deplete the interior imine ring from the peptide backbone leading to the deletion of an internal lysine residue.
\end{abstract}

Key words: Synthetic peptide, Electrospray ionization, Collisional activation, Water-loss, Internal lysine deletion, Cyclic imine intermediate

\section{Introduction}

$\mathrm{P}$ recise determination of the sequence of amino acids in a protein is important for protein profiling such as in the study of the roles of specific proteins in diseases and for the discovery of potential biomarkers as well as of targets for therapy of diseases [1-4]. Mass spectrometry-based methods have become extremely popular for high throughput assay of

Electronic supplementary material The online version of this article (doi:10.1007/s13361-012-0456-1) contains supplementary material, which is available to authorized users.

Correspondence to: Shyamalava Mazumdar; e-mail: shyamal@tifr.res.in proteins in biofluids, especially in a small quantity of complex mixture [4]. The sequences of individual peptides produced by enzymatic digestion of a protein are derived from the identification of the gas-phase peptide ion fragments by collision-induced dissociation (CID) in tandem mass spectrometry (MS/MS) [5-9].

The mass selected protonated peptide undergoes fragmentation on collisional activation and the success of the tandem mass spectrometric identification of the peptides depends on the understanding of the mechanism of fragmentation of the peptide ions. The gaseous peptide fragmentation model based on cleavage of the peptide backbone, is now implemented in various sequencing algorithms to analyze the MS/MS spectra of peptides [10]. However, only 
a small fraction of the acquired ion signals in the MS/MS spectrum of a peptide can be assigned unambiguously by the existing sequencing programs. The majority of the signals in the tandem mass spectrum of a peptide ion still remain unassigned. When a gaseous protonated peptide is collisionally excited, it follows several complicated dissociation pathways and only a few of them are well studied. So the understanding of the mechanism of the formation of any anomalous fragment ion that cannot be assigned by the conventional model of peptide dissociation would no doubt help to improve and modify the sequencing algorithms used in proteomics.

The collisional excitation of the protonated peptide leads to transfer the ionizing proton from an unreactive site of higher gas-phase basicity (e.g., Arg, Lys, and His side chain or $\mathrm{N}$-terminal $\alpha-\mathrm{NH}_{2}$ group) to energetically less favored and reactive backbone-amide(s) and carbonyl(s) in the mobile proton model [11, 12]. Fast proton transfer to various backbone amide bonds results in the formation of the primary fragment ions e.g. N-terminal $a-, b-, c$-ions and Cterminal $x$-, $y$-, and $z$-ions $[9,13]$ that are used for sequence identification of the peptide. Under low energy collision condition, $a, b$ and $y$-fragments are abundant. The $b$-ion was proposed to exist as cyclic oxazolone structure and/or headto-tail macrocyclic structure in the gas phase [14-16]. Increase in the activation time (i.e., in multiple collision condition), the primary fragment ions can further dissociate to secondary ions (satellites) such as internal fragments [17], amino acid specific immonium ions [18], neutral loss $a / b / y$ ions (e.g., $b_{n}-\mathrm{NH}_{3}$ or $b_{n}-\mathrm{H}_{2} \mathrm{O}$ etc.) $[19,20]$ and smaller member of $a-, b$-, and $y$-ion series. All these ions are directly related to the sequence of the peptide and hence they have been referred to as direct sequence ions [21].

However, the majority of the fragment ions detected in the MS/MS spectrum of a peptide often cannot be classified as direct sequence ions [22-25]. These fragments are formed by complex rearrangements of the ions and termed as nondirect sequence ions [21]. There are a few such nondirect sequence ions have been identified recently, such as scrambled fragments of the $b / a$ type ions resulting in the loss of an amino acid residue from the interior of the peptide chain $[21,26]$. The first step of such loss of an internal amino acid by sequence scrambling fragmentation pathway was proposed [21, 27-32] to involve a nucleophilic attack by N-terminal $\alpha-\mathrm{NH}_{2}$ group on the acylium carbocation of the $b$-ion (a primary fragment) forming a protonated cyclicpeptide intermediate (CPI). This CPI subsequently undergoes ring opening at different amide bonds producing sequence scrambled linear $b$-ions. These scrambled linear $b$-ions undergo further dissociation by conventional fragmentation pathway to produce corresponding daughter ions that are not related to the original sequence of the peptide $[21,27-32]$. Thus such ions, called the nondirect sequence ions, would be related to all the possible scrambled sequences of the peptide, and therefore would loss the memory of the original sequence. At the first stage of CID, this unique fragmentation of the cyclic $b$-ion is difficult to be observed.[21, 33, 34] However under multi stage CID $\left(\mathrm{MS}^{\mathrm{n}}\right)$, these $b$-ions (containing 3-9 amino acid residues) were shown to follow the above scrambled fragmentation pathways [21, 27-32, 35, 36]. The propensity of the above sequence scrambling increases with the increase in the chain length and charge states of the peptides [37].

In this report, we present a detailed study of the gas-phase fragmentation of a series of synthetic octapeptides of different sequences containing six alanines and two lysines. The results show that the internal lysine residues of these peptides are selectively lost upon collisional activation. The mechanism of deletion of the internal lysine residue has been investigated by multi stage CID, chemical, and isotopic modification of the peptides and energy resolved CID techniques. Our results suggest that this selective deletion of the lysine residue from the interior of the peptide may not follow the sequence scrambling fragmentation pathway as reported earlier [21, 27-32]. A novel gas-phase peptide ion degradation pathway has been shown to be responsible for the specific loss of the internal lysine residues in the peptide.

\section{Experimental}

\section{Chemicals}

Fmoc-Ala-OH, Fmoc-Lys(Boc)-OH, Fmoc-Tyr(tBu)-OH, Fmoc-Gly-OH, Fmoc-Leu-OH, Fmoc-Phe-OH, and 2-(1-Hbenzotriazol-1-yl)-1,1,3,3-tetramethyl-uronium hexafluorophosphate (HBTU) were obtained from Novabiochem (Merck, Hohenbrunn, Germany). Fmoc-Rink amide MBHA resin LL (100-200 mesh), triisopropylsilane (TIS), methyl tert-butyl ether (MTBE), and GC grade methanol were purchased from Merck. DMF, piperidine, $N$-methylmorpholine (NMM), triethanolamine, acetic anhydride, and formaldehyde were provided by S.D. Fine-Chem Ltd. Mumbai, India. Borane pyridine complex $\left(\sim 8 \mathrm{M} \mathrm{BH}_{3}\right)$ and Fmoc-Lys(Boc)-OH- ${ }^{13} \mathrm{C}_{6},{ }^{15} \mathrm{~N}_{2}$ (98 atom \%) were obtained from Sigma-Aldrich, St. Louis, MO, USA. HPLC grade acetic acid and trifluoroacetic acid (TFA) were purchased from Spectrochem Pvt. Ltd. Mumbai, India.

\section{Synthesis of C-Terminal Amidated Peptides [38]}

Standard Fmoc solid-phase peptide synthesis technique was employed to prepare resin-bound linear peptides AKAAA KAA, AAAKKAAA, KAAAKAAA, KAAAAAAK, AAAKAAA, AKAAAK*AA (the sixth lysine residue is isotopically labeled) and YAKGFKL, either manually or in batch mode on an automated peptide synthesizer (PS3 by Protein Technologies, Inc. Arizona, USA) at $0.1 \mathrm{mmol}$ scale using a fourfold excess of Fmoc-amino acids relative to Fmoc-Rink amide MBHA resin $(0.39 \mathrm{mmol} / \mathrm{g})$. Deprotection was performed using $20 \%$ piperidine/DMF. Coupling was performed using 1:1:2 amino acid/HBTU/NMM in DMF. DMF top washes $(1 \mathrm{~min})$ were performed between deprotection and coupling steps. The peptides were cleaved from 
resin using $2.5 \%$ triisopropylsilane (TIS), $2.5 \%$ water, $95 \%$ TFA solution at room temperature for $3 \mathrm{~h}$. The volatiles were removed under a stream of nitrogen gas, and peptides precipitated with methyl tert-butyl ether. Then it was centrifuged and peptides were collected as trifluoroacetate salt. The peptides were purified by reversed-phase highperformance liquid chromatography (RP-HPLC).

\section{Selective $N$-Terminal $\alpha$-Aminoacetylation of the Peptides [38]}

The resin bound peptides (where the N-terminus $\alpha-\mathrm{NH}_{2}$ is free but $\varepsilon-\mathrm{NH}_{2}$ of lysines are BOC protected) obtained from the above procedure was allowed to react with 100 -fold excess acetic anhydride in the same fashion as above amide bond formation. This led to the selective acylation of the $\mathrm{N}$ terminus $\alpha-\mathrm{NH}_{2}$ of the peptides. The acetylated peptides were then cleaved from the resin and $\varepsilon-\mathrm{NH}_{2}$ of lysines were deprotected following the same process as above to get target $\mathrm{N}$-terminal $\alpha$-aminoacetylpeptides. The product was purified by RP-HPLC.

\section{Reductive Methylation of the Amine Functional Groups in the Peptides [39]}

Peptides $(1.25 \mathrm{mg})$ were dissolved in $1 \mathrm{~mL} 300 \mathrm{mM}$ triethanolamine buffers ( $\mathrm{pH}$ 7.5). The reactions were diluted to $1 \mathrm{mg} / \mathrm{mL}$ with methanol. Pyridine- $\mathrm{BH}_{3}(8 \mathrm{M}$ in excess pyridine) was added to $30 \mathrm{mM}$. Last, formaldehyde was added to $20 \mathrm{mM}$. Reactions were then sonicated briefly in a water bath $(1 \mathrm{~min})$ to suspend pyridine- $\mathrm{BH}_{3}$ and allowed to react at room temperature for $2 \mathrm{~h}$. Then it was lyophilized and the products were taken for mass spectrometric experiments without further purification.

\section{ESI-MS Experimental Condition}

Electrospray ionization mass spectrometry (ESI-MS) studies $[10,40]$ were carried out using a Thermo Finnigan LCQ Deca (San Jose, CA, USA) Electrospray quadrupole ion trap mass spectrometer [38, 41-43]. All the experiments were carried out under the identical conditions. The flow rate of the analyte solution was maintained at $5 \mu \mathrm{L} / \mathrm{min}$. Nitrogen was used as the sheath gas. The ion source conditions were: sheath gas flow rate 20 units (arbitrary for the Finnigan systems, corresponding to $\sim 0.375 \mathrm{~L} / \mathrm{min}$ ). Capillary (desolvation) temperature was maintained at approximately $200{ }^{\circ} \mathrm{C}$ and capillary voltage was kept at $15 \mathrm{~V}$. The ionspray voltage and tube lens offset were maintained at $4.5 \mathrm{kV}$ and $-7 \mathrm{~V}$ respectively. The ion optics were tuned by using autotune routine within the LCQ Tune program to get maximum ion count. The sample concentration was $\sim 100 \mu \mathrm{M}$ for each peptide. Helium was used as the bath/ buffer gas to improve trapping efficiency and as the collision gas in the collision cell (ion trap) for collision-induced dissociation (CID) experiments.
Low-energy CID spectra (MS/MS and $\mathrm{MS}^{\mathrm{n}}$ ) were acquired using an isolation width of $2 \mathrm{~m} / \mathrm{z}$ unit. The activation Q (as labeled by Thermo Finnigan, used to adjust the $\mathrm{q}_{\mathrm{z}}$ value [10] for the precursor ion) was set at 0.250 , and the activation time employed was $30 \mathrm{~ms}$ at each CID stage. The normalized collision energy (which defines the amplitude of the RF energy applied to the end-cap electrodes in the CID experiments) was set between $25 \%$ and $30 \%$ for multi stage CID experiments $\left(\mathrm{MS}^{\mathrm{n}}\right)$ and it was varied from $10 \%$ to $55 \%$ for the dissociation profile (breakdown) study of the mass selected ions. Data acquisition was performed for $1 \mathrm{~min}$ using XCalibur software (Thermo Fisher Scientific).

\section{Results and Discussion}

The ESI-MS spectra of all the isomeric octapeptides (AKAAAKAA- $\mathrm{NH}_{2}$, AAAKKAAA- $\mathrm{NH}_{2}$, KAAAKAAA$\mathrm{NH}_{2}$, KAAAAAAK-NH $\mathrm{N}_{2}$, AAAKAAAK- $\mathrm{NH}_{2}$ ) produced singly protonated species $[\mathrm{M}+\mathrm{H}]^{+}$at $\mathrm{m} / z 700.5$ and doubly protonated species $[\mathrm{M}+2 \mathrm{H}]^{+}$at $m / z 350.8$ in the gas phase (see Figure $\mathrm{S} 1$ in the Supporting Information). Collisional activation (MS/MS) of the singly protonated peptide $[\mathrm{M}+\mathrm{H}]^{+}$ $\left(\mathrm{m} / z\right.$ 700.5) produced the characteristic $b_{n}$ and $y_{n}$ ions (see Figure 1). Figure 1 shows that the major fragment ion (base peak) is the $b_{8}$-ion (at $m / z 683.5$ ), which is produced by the loss of $\mathrm{NH}_{3}$ from the $\mathrm{C}$-terminal protonated carboxamide functional group of the peptides.

\section{Neutral Loss of Water}

(a) Correlation with the Number of Lysine Residues. A close inspection of all the $\mathrm{MS}^{2}$ spectra (Figure 1) shows that the sequence informative ions $\left(b_{n}\right.$ and $\left.y_{n}\right)$ undergo neutral loss of one or two water molecules. The maximum number of water-loss from a $b_{n}$-ion is found to be equal to the number of lysine residues present in that ion. For example, the maximum number of water loss observed from $b_{8}$-ion of AKAAAKAA- $\mathrm{NH}_{2}$ is two, while only one water-loss is observed from $b_{5}, b_{4}$, and $b_{3}$-ion of this peptide. This observation clearly correlates the number of water loss with the number of lysine residues in the $b_{n}$-ion, suggesting that the lysine residues are involved in the water-loss mechanism.

(b) Involvement of Lysine Side Chain Amine in the WaterLoss Mechanism: Chemical Modification of the Peptide In order to test the role of the lysine residues in the water-loss mechanism, we modified the amine functional groups ( $\mathrm{N}$-terminal $\alpha-\mathrm{NH}_{2}$ and side chain $\varepsilon-\mathrm{NH}_{2}$ of lysines) in all the isomeric octapeptides by amine reductive methylation reaction [39]. The modified peptides were identified by ESI-MS spectra (see Figure S2 in the Supporting Information). The peaks at $\mathrm{m} / \mathrm{z}$ 

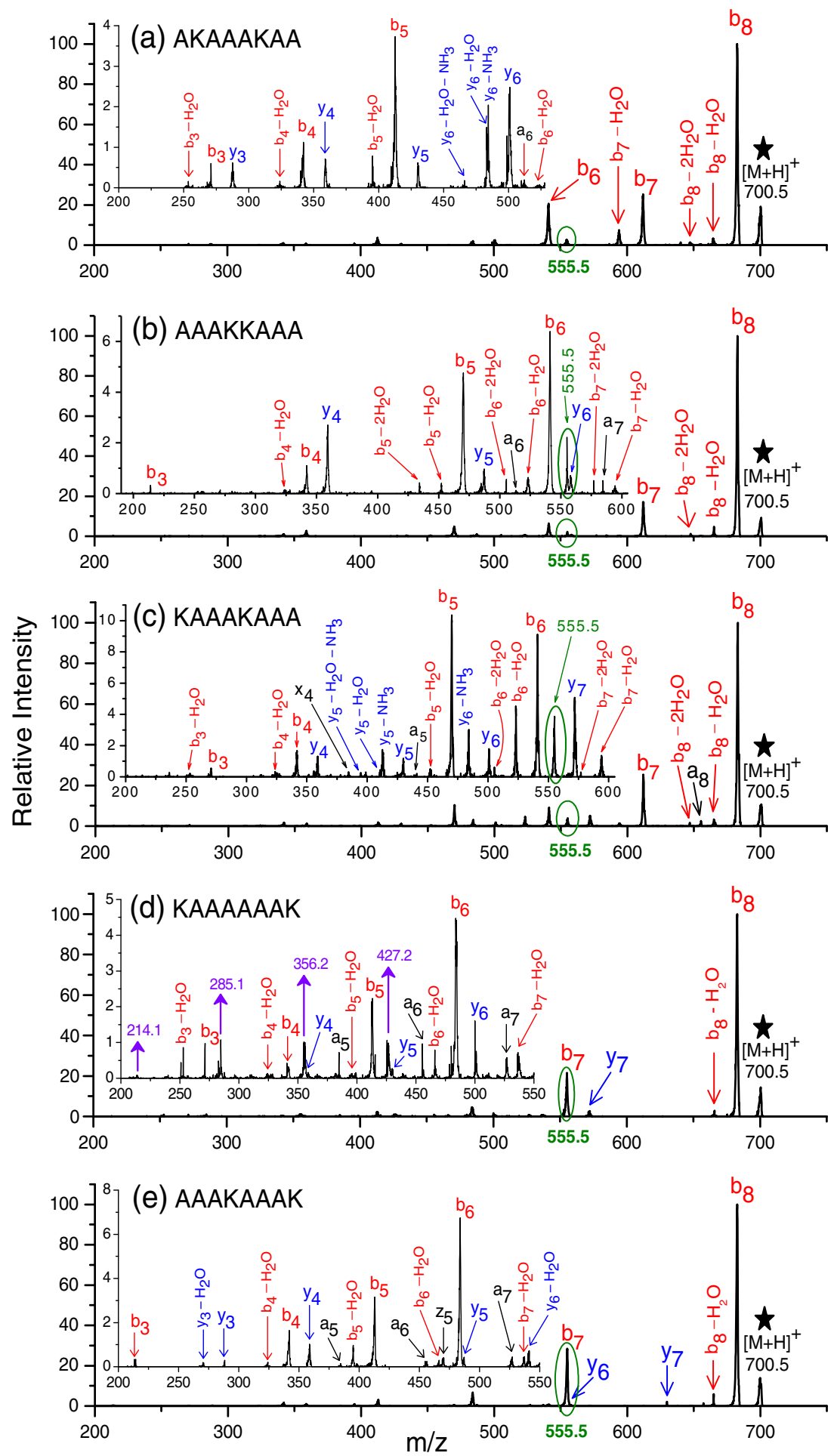

Figure 1. Low energy CID-MS/MS spectra $\left(\mathrm{MS}^{2}\right)$ of the singly protonated peptide ions $[\mathrm{M}+\mathrm{H}]^{+}(\mathrm{m} / z$ 700.5) of the peptides (a) AKAAAKAA-NH ${ }_{2}$, (b) AAAKKAAA- $\mathrm{NH}_{2}$, (c) KAAAKAAA-NH ${ }_{2}$, (d) KAAAAAAK-NH $\mathrm{N}_{2}$, and (e) AAAKAAAK-NH $\mathrm{N}_{2}$. The inset of each spectrum is the enlarged view of the low $\mathrm{m} / \mathrm{z}$ range to show all the CID product ions observed. No ion signal was observed below $\mathrm{m} / \mathrm{z} 200$. For convenience the $\mathrm{y}$-ions have been labeled using blue color, b-ions using red color and other ions using black color. Internal fragments appeared due to the preferential loss of $\mathrm{N}$-terminal lysine from the $b_{n}$-ions of KAAAAAAK-NH ${ }_{2}$ are shown by purple arrow in the inset of (d)

784.5 correspond to the singly protonated hexamethylated products of all the peptides. Thus all the primary- amines in the peptides are converted into the tertiaryamines upon $N, N$-dimethylation reaction. The tandem mass 
spectra $\left(\mathrm{MS}^{2}\right)$ of the singly protonated species of each of these modified peptides are shown in Figure 2. Unlike in the case of the unmodified peptides (Figure 1), the $b_{n}$-ions of the modified peptides do not undergo any neutral loss of water. In fact none of the sequence informative fragment ions (e.g., $a_{n}, b_{n}$, and $y_{n}$ ) of the modified peptides show neutral loss of water. The most intense peak (base peak) is the $b_{8}$-ion corresponding to the loss of $\mathrm{NH}_{3}$ from the protonated $\mathrm{C}$ terminal amide (Figure 2) analogous to that observed in the unmodified peptides (Figure 1). This result strongly
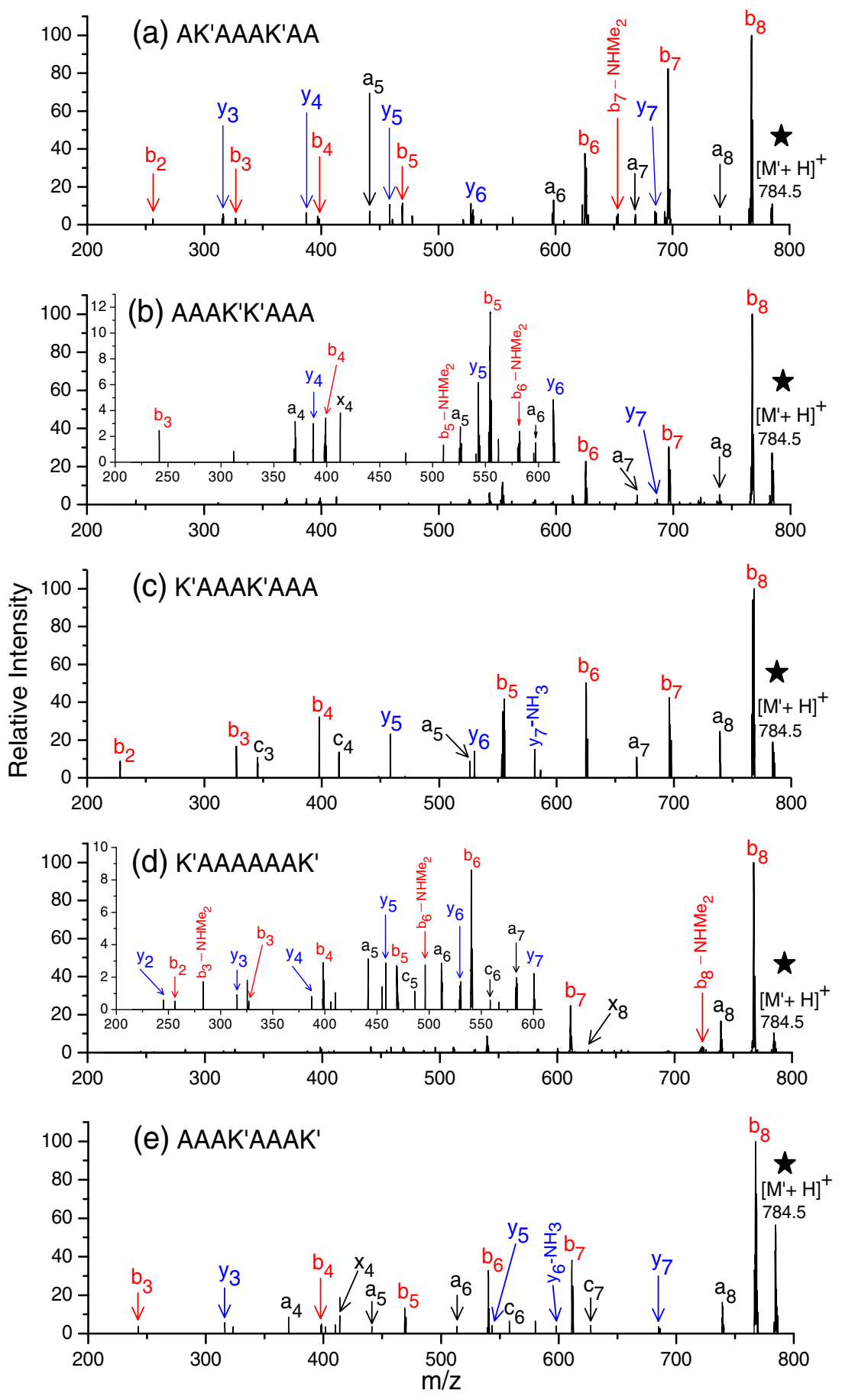

Figure 2. Low energy CID-MS/MS spectra $\left(\mathrm{MS}^{2}\right)$ of the singly protonated aminomethylated-products $\left[\mathrm{M}^{\prime}+\mathrm{H}\right]^{+}(\mathrm{m} / z 784.5)$ of the peptides (a) AKAAAKAA-NH $\mathrm{N}_{2}$, (b) AAAKKAAA-NH $\mathrm{N}_{2}$, (c) KAAAKAAA-NH $\mathrm{N}_{2}$, (d) KAAAAAAK-NH ${ }_{2}$, and (e) AAAKAAAK-NH 2 . In the Figure prime symbol on each lysine residue $\left(K^{\prime}\right)$ indicates that the lysine side chain amine is methylated by two methyl groups. The N-terminal a-amine is also methylated in each peptide. The inset of the panels (b) and (d) are the enlarged views of the low $\mathrm{m} / \mathrm{z}$ range to show all the CID product ions observed. No ion signal was observed below $\mathrm{m} / \mathrm{z} 200$. For convenience, the $\mathrm{y}$-ions have been labeled using blue color, b-ions using red color, and other ions using black color 
suggests that the primary-amine functional groups of the lysine containing peptides are involved in the loss of water.

In order to determine whether the N-terminal $\alpha-\mathrm{NH}_{2}$ group or the lysine $\varepsilon-\mathrm{NH}_{2}$ group is involved in the waterloss mechanism, we selectively modified this $\mathrm{N}$-terminal $\alpha$ $\mathrm{NH}_{2}$ group of the peptides by acetylation [38]. The tandem mass spectra of all the $\alpha$-aminoacetyl peptides (see Figures S3, S4, and S5 for three typical peptides Ac-AKAAAKAA$\mathrm{NH}_{2}$, Ac-AAAKKAAA- $\mathrm{NH}_{2}$, and Ac-KAAAKAAA$\mathrm{NH}_{2}$, respectively) show that the maximum number of water loss from the fragment ions is equal to the number of lysine residue present in that ion analogous to that observed in case of the unmodified peptides (Figure 1). These results thus clearly suggest that the lysine side chain amines are indeed involved in the mechanism to loss the water molecule from the protonated peptides in the gas phase.

The possible mechanism of this water elimination could be the acid $\left(\mathrm{H}^{+}\right)$catalyzed unimolecular dehydration reaction between the lysine $\varepsilon-\mathrm{NH}_{2}$ group and the carbonyl group of a suitable amide in the peptide backbone. This would lead to the formation of a cyclic imine fused to the peptide backbone (Scheme 1). According to the mobile proton model [11, 12, 44, 45], the collisionally activated protonated peptides would have protonation at all the possible sites (hetero atoms) including the backbone carbonyls of the amides. The Scheme 1 shows that the side chain lysine amine acts as the nucleophile and the carbon center of one of the carbonyl groups of the peptide backbone acts as an electrophile on protonation of the amide carbonyl oxygen. Thus the water eliminated species observed in the tandem mass spectra of the lysine containing octapeptides (Figure 1) are possibly cyclic imines fused to the peptide backbone as proposed in Scheme 1 .

(c) Identification of the Amide Carbonyl Involved in the Cyclic Imine Formation: Multistage CID Study

Multistage CID experiments $\left(\mathrm{MS}^{\mathrm{n}}\right)$ were carried out to identify the electrophilic carbonyl carbon that is attacked by the nucleophile (lysine side chain amine) to form the cyclic

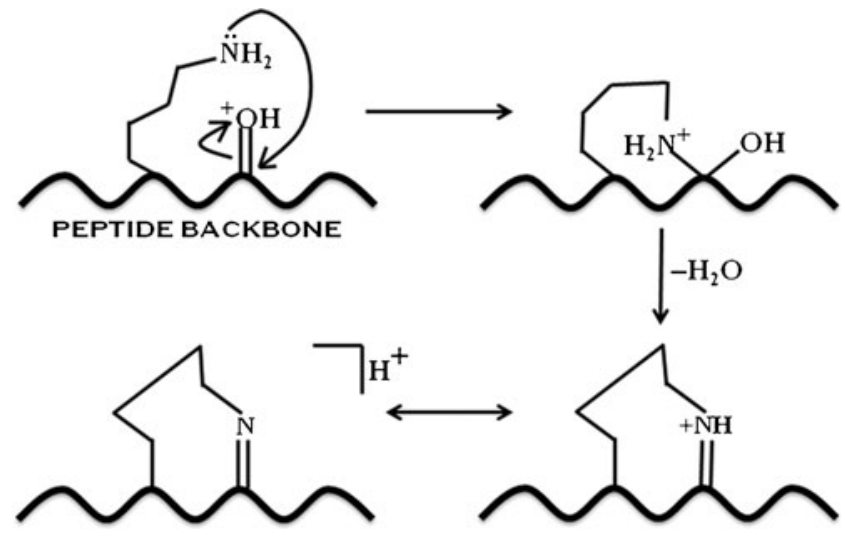

Scheme 1. A tentative mechanism of the dehydration reaction of the peptide under investigation imine. The $b_{8}$-ions were mass selected from the $\mathrm{MS}^{2}$ spectra (Figure 1) of all the singly protonated isomeric octapeptides and subjected to further CID to obtain the $\mathrm{MS}^{3}$ spectra (Figure 3). Figure 3 shows very intense ion abundance for the species $\left[b_{8}-\mathrm{H}_{2} \mathrm{O}\right]^{+}(m / z$ 665.5) in the case of the three peptides AKAAAKAA- $\mathrm{NH}_{2}$, AAAKKAAA- $\mathrm{NH}_{2}$, and KAAAKAAA- $\mathrm{NH}_{2}$ (Figure 3a-c), unlike in the case of the peptides KAAAAAAK- $\mathrm{NH}_{2}$, AAAKAAAK- $\mathrm{NH}_{2}$ that contained a lysine residue at the $\mathrm{C}$-terminal (Figure $3 \mathrm{~d}$ and e). The peptides containing C-terminal lysine rather showed the $b_{7}$-ions (base peak) as the most abundant species indicating collisional activation $\left(\mathrm{MS}^{3}\right)$ causes preferential loss of a C-terminal neutral lysine, which possibly exists as a cyclic amide form ( $\varepsilon$-caprolactam) [46] (Figure $3 \mathrm{~d}$ and e). The water-loss ions $\left[b_{8}-\mathrm{H}_{2} \mathrm{O}\right]^{+}(\mathrm{m} / z$ 665.5) mass selected from the $\mathrm{MS}^{3}$ spectra (Figure $3 \mathrm{a}-\mathrm{c}$ ) were subjected to further CID to obtain the corresponding $\mathrm{MS}^{4}$ spectra (see Figure S6 in the Supporting Information). The MS ${ }^{4}$ spectra showed loss of two water molecules in some product ions (i.e., $a_{n}-2 \mathrm{H}_{2} \mathrm{O}, b_{n}-2 \mathrm{H}_{2} \mathrm{O}$, and/or $y_{n}-$ $2 \mathrm{H}_{2} \mathrm{O}$ ions) that contained two lysine residues, while only a single water loss was observed for the product ions (i.e., $a_{n}-\mathrm{H}_{2} \mathrm{O}, b_{n}-\mathrm{H}_{2} \mathrm{O}$, and/or $y_{n}-\mathrm{H}_{2} \mathrm{O}$ ions) that contained single lysine residue. Thus, the $\mathrm{MS}^{4}$ spectrum for the peptide AAAKKAAA- $\mathrm{NH}_{2}$ showed no water loss from $b_{3}$ and $y_{3}$-ions (that contained no lysine residues) but single water loss from $b_{4^{-}}, y_{4^{-}}$ions (contain only one lysine residue) and double water loss from the product ions containing two lysine residues (e.g., $b_{5^{-}}, b_{6^{-}}, b_{7^{-}}, b_{8^{-}}$, or $y_{5^{-}}, y_{6^{-}}, y_{7^{-}}$-ions (see S6b in the Supporting Information). The observation of the waterloss ions in the $\mathrm{MS}^{4}$ spectra can be used for mass finger printing in identifying the amide carbonyl that is involved in the formation of the cyclic imine (see Scheme S1 in the supporting information). For example, the detection of double water loss from $b_{\sigma^{-}}$and $y_{7}$-ions and single water loss from $b_{5^{-}}$and $y_{6}$-ions in the $\mathrm{MS}^{4}$ spectrum of the peptide AKAAAKAA- $\mathrm{NH}_{2}$ (see S6a in the Supporting Information) supports formation of a seven-membered cyclic imine on water loss from the lysine containing peptide (see Scheme S1 (B) in the Supporting Information). These results thus clearly suggest that the carbonyl carbon of the $i^{\text {th }}$ lysine residue is attacked by the nucleophilic $\varepsilon-\mathrm{NH}_{2}$ of the same lysine residue ( $i-i$ cyclization) to form the seven-membered cyclic imine (see Scheme S1 (B) in the Supporting Information) fused to the peptide backbone by losing one water molecule. The simultaneous possibilities of side reactions involving formation of larger cyclic imines [eg., by $i-(i \pm 1)$ ] cyclization can however not be ruled out from the present results.

\section{Deletion of Internal Lysine Residue}

(a) The Assignment of the Peak at $\mathrm{m} / \mathrm{z} 555.5$ in the CID Spectra 

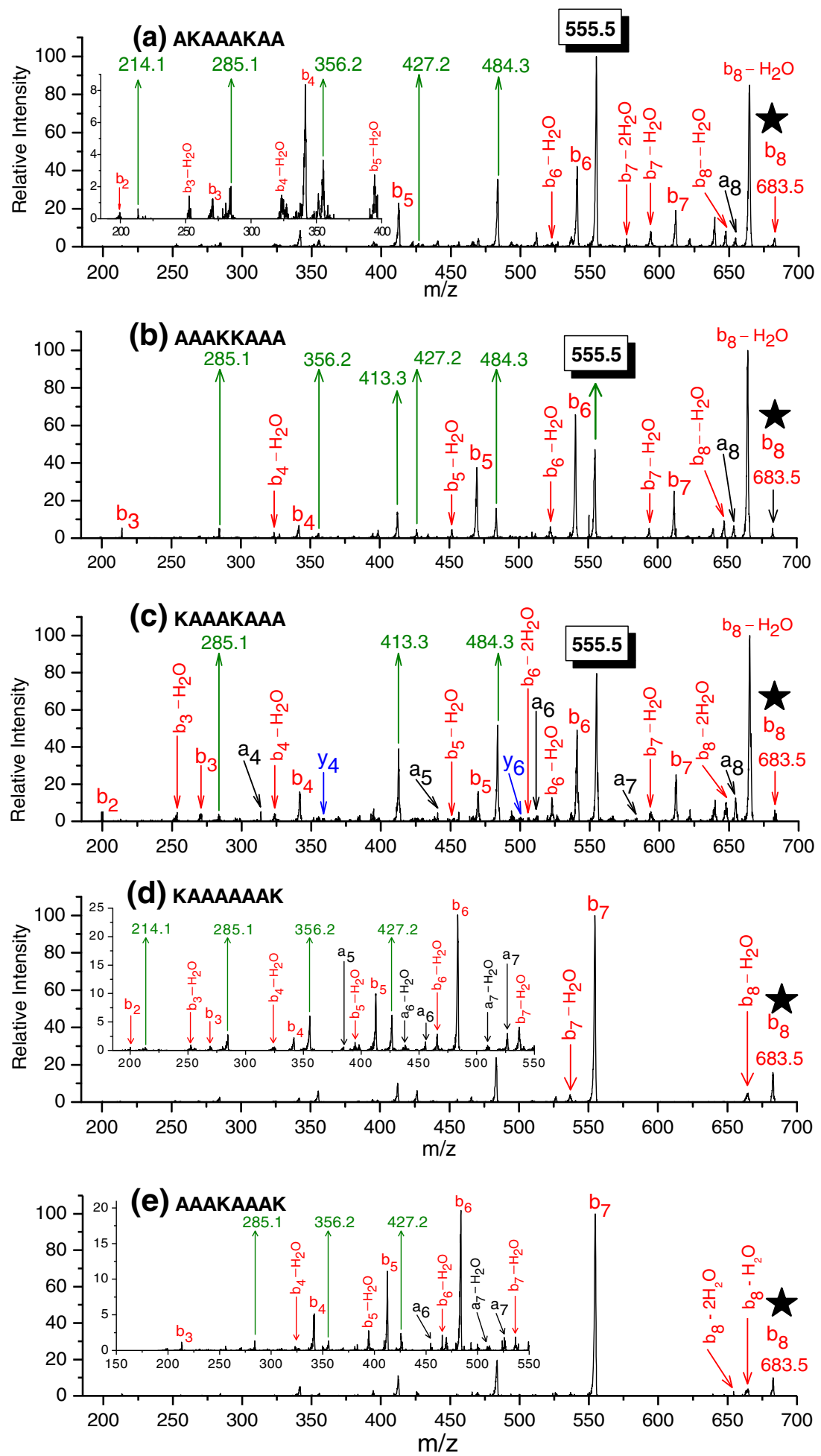

Figure 3. CID-MS ${ }^{3}$ spectra of the $b_{8}$-ions at $m / z 683.5$ for the peptides (a) AKAAAKAA-NH ${ }_{2}$, (b) AAAKKAAA-NH ${ }_{2}$, (c) KAAAKAAA- $\mathrm{NH}_{2}$, (d) KAAAAAAK-NH ${ }_{2}$, and (e) AAAKAAAK- $\mathrm{NH}_{2}$. The inset of the panels (a) (d) and (e) are the enlarged view of the low $\mathrm{m} / \mathrm{z}$ range to show all the CID product ions observed. No ion signal was observed below $\mathrm{m} / \mathrm{z} 200$. For convenience the $y$-ions have been labeled using blue color, b-ions using red color and other ions using black color. The nonsequence ion fragments, appeared due to the internal lysine deletion, have been shown using green colored vertical arrow

The $\mathrm{MS}^{2}$ spectra of the isomeric octapeptides $[\mathrm{M}+\mathrm{H}]^{+}$ $(\mathrm{m} / \mathrm{z}$ 700.5) showed a peak corresponding to a singly charged ion at $\mathrm{m} / \mathrm{z} 555.5$ (Figure 1). This ion signal is more intense for the peptides with the C-terminal lysine 
(viz., KAAAAAAK- $\mathrm{NH}_{2}$ and AAAKAAAK-NH $\mathrm{N}_{2}$ ) compared with the other three peptides and corresponds to a difference in the $\mathrm{m} / \mathrm{z}$ value of $145 \mathrm{u}$ from the protonated peptide. This ion signal matches with the expected $b_{7^{-}}$ ion (Figure 1d and e) produced by the neutral loss of amidated lysine (mass $145 \mathrm{u}$ ) from the C-terminus of these two peptides (containing C-terminal lysine). However, this ion signal $(\mathrm{m} / \mathrm{z} 555.5)$ in the other three peptides (Figure 1a-c) does not correspond to any direct sequence ion $\left(a_{n}, b_{n}, x_{n}, y_{n}\right)$ or their neutral loss (water or ammonia) species. It is interesting to note that this ion signal is consistently observed in all peptides even in the $\mathrm{MS}^{3}$ spectra (Figure $3 \mathrm{a}-\mathrm{e}$ ) obtained by CID of the mass selected $b_{8}$-ions from the $\mathrm{MS}^{2}$ of the protonated peptides. The relative ion abundance of this non sequence ion signal $(\mathrm{m} / \mathrm{z} 555.5)$ increases from $\sim 2 \%$ $4 \%$ in the $\mathrm{MS}^{2}$ spectra (Figure $1 \mathrm{a}-\mathrm{c}$ ) to $\sim 50 \%-100 \%$ in the $\mathrm{MS}^{3}$ spectra (Figure $3 \mathrm{a}-\mathrm{c}$ ) in case of these three peptides. Moreover, the ion abundance of this peak in the $\mathrm{MS}^{2}$ spectra (Figure $1 \mathrm{a}-\mathrm{c}$ ) increases with the normalized collision energy. The energy resolved CID $\left(\mathrm{MS}^{2}\right)$ results (Figure S7 in the Supporting Information) showed that the fractional abundance of this nonsequence ion $(\mathrm{m} / \mathrm{z} 555.5)$ is highest at the normalized collision energy $\sim 45 \%$ and further increase in the collision energy leads to decrease in the abundance of this ion.

(b) Possible Structure of the Ion Fragment at $\mathrm{m} / \mathrm{z}$ 555.5: Multistage CID study

As discussed above, the singly charged ion of $m / z 555.5$, formed by loss of $145 \mathrm{u}$ from the protonated peptide $[\mathrm{M}+\mathrm{H}]^{+}$ion possibly corresponds to the loss an amidated lysine or to the simultaneous loss of a lysine residue and an ammonia molecule. Figure $1 \mathrm{~d}$ and e suggests that this ion could be formed by the loss of the terminal amidated lysine from the peptides KAAAAAAK- $\mathrm{NH}_{2}$ and AAAKAAAK- $\mathrm{NH}_{2}$ and corresponds to the direct sequence $b_{7}$-ion in these two peptides. However, the non sequence ion at $\mathrm{m} / \mathrm{z} 555.5$ observed in case of the other three peptides (Figure $1 \mathrm{a}-\mathrm{c}$ ) cannot be directly formed by loss of the terminal residue, rather the simultaneous loss of an Nterminal or an internal lysine (residue mass $128 \mathrm{u}$ ) and an ammonia molecule $(17 \mathrm{u})$ may give rise to this species. In order to ascertain the origin of this non sequence ion, CID studies of the mass selected ions $(m / z 555.5)$ from the $\mathrm{MS}^{3}$ spectra (Figure 3a-c) were carried out (Figure 4).

The possible sequences of the ion at $\mathrm{m} / \mathrm{z} 555.5$ produced from each of the octapeptides were derived from the analyses of the mass finger prints in the $\mathrm{MS}^{4}$ spectra (Figure 4). The results in Figure 4a-c suggest that this ion is produced by the loss of any one of the two lysine residues either from the inside or from the Nterminal of the peptide along with a neutral loss of ammonia from the C-terminal amide. This also may be produced by the loss of one lysine residue from the corresponding $b_{8}$-ions of the peptides. Apart from the sequence informative ions of the $m / z 555.5$ species, Figure 4 also shows the fragment ions ( $a_{n^{-}}, b_{n}$-ions) corresponding to the CID of the hexapeptide AAAAAA suggesting that both the lysine residues are deleted from the peptides at the $\mathrm{MS}^{4}$ stage. Scheme 2 summarizes the gas-phase reactions described above for a typical peptide AKAAAKAA- $\mathrm{NH}_{2}$.

\section{(c) Mechanism of the Internal Lysine Deletion}

Though a simple mechanistic explanation based on the established fragmentation rules [7] can account for the neutral loss of terminal lysine (C-/N-terminal) through formation of $b_{n}$ - or $y_{n}$ ions from the protonated peptide, the internal lysine loss in the present case cannot be described by such mechanism.

Recent studies [21, 27-32] have shown that the $b_{n}$-ions and their analogues of a peptide may undergo head-totail cyclization, forming a protonated cyclic intermediate through the nucleophilic attack by the N-terminal $\alpha$ amino group on the carbonyl carbon of the $\mathrm{C}$-terminal oxazolone ring. The authors showed that this cyclic protonated peptide intermediate [21, 27-32] undergoes ring opening at different amide bonds to form a series of the linear oxazolone terminated $b_{n}$-ions of scrambled sequences. The cyclization and subsequent ring-opening process, was thus proposed to lead to scrambling of the original primary sequence of the $b_{n}$-ions, which upon collisional activation could form the daughter ions corresponding to the neutral loss of an internal residue from the peptide. Selective deletion of internal lysine by sequence scrambling following the head-to-tail macrocyclization cannot indeed be completely ruled out in the present case, though no evidence of the deletion of internal alanine as anticipated from the proposed random scrambling [21,27-32] of the peptide sequence was observed in our results.

In order to assess whether head-to-tail macrocyclization of the $b_{n}$-ion (as discussed above) could be a major pathway for the internal lysine deletion, we selectively acetylated the $\mathrm{N}$-terminal $\alpha$-amine of the peptides since $\mathrm{N}$-acetylation blocks the macrocyclization [28, 47]. It is interesting to note that the deletion of internal lysine by collisional activation of the protonated octapeptides as described above (Figure 1 and Figure 3) indeed takes place even after the N-acetylation (see Figures S3, S4, and S5 in the Supporting Information) of the peptides ( $\mathrm{m} / \mathrm{z}$ 742.4, the singly protonated N-acetylated peptides). Analogous to that observed for the unmodified peptides, the results in the tandem mass spectra (Figures S3, S4, and S5 in the Supporting Information) show that an ion signal ( $m / z 597.4)$ corresponding to the loss of $145 \mathrm{u}$ (residue mass of Lys + mass of $\mathrm{NH}_{3}$ ) from the protonated $\mathrm{N}$-acetylated peptides suggesting deletion of internal lysine residue. This indicates that the deletion of internal lysine as observed in the present case may also occur in a different pathway other than the sequence scrambling fragmentation pathway [21, 27-32]. 

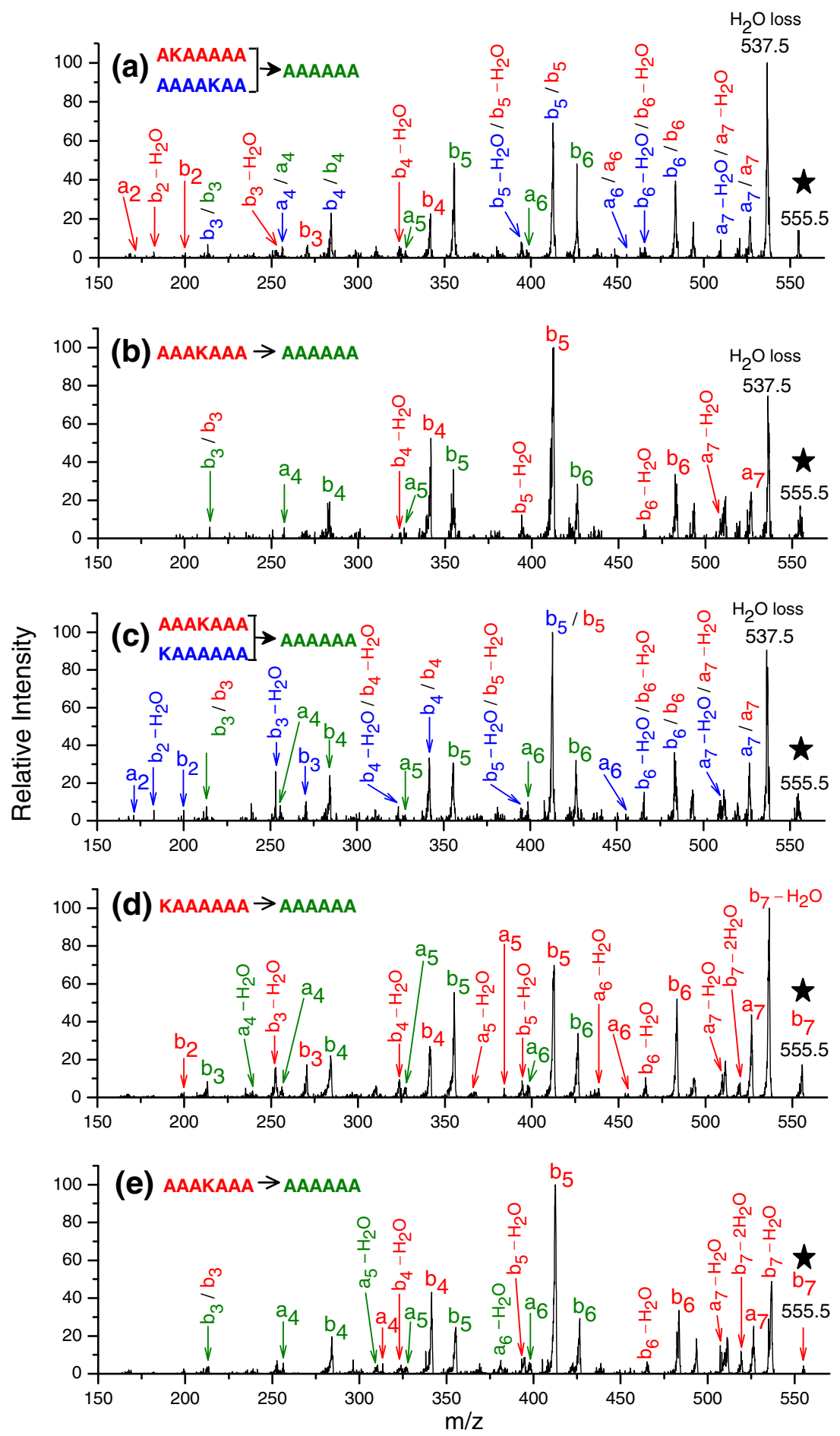

Figure 4. CID-MS ${ }^{4}$ spectra of the fragment ions at $m / z 555.5$ from the peptides (a) AKAAAKAA-NH ${ }_{2}$, (b) AAAKKAAA-NH ${ }_{2}$, (c) KAAAKAAA- $\mathrm{NH}_{2}$, (d) KAAAAAAK- $\mathrm{NH}_{2}$, and (e) AAAKAAAK- $\mathrm{NH}_{2}$ under the same collision energy (28\%). No ion signal was observed below $\mathrm{m} / \mathrm{z}$ 150. In each panel of the figure, different colors have been used to label the fragment ions of the same colored amino acid sequence shown in top left corner of each panel

Furthermore, collisional activation $\left(\mathrm{MS}^{2}\right)$ of the aminomethylated peptides $(m / z$ 784.5) shown in Figure 2a-c did not show any ion signal at $\mathrm{m} / \mathrm{z} 611.5$ corresponding to the deletion of an internal lysine (methylated). The aminomethylated octapeptides containing a lysine residue at the $\mathrm{C}$ - terminal however showed the direct sequence ion ( $b_{7}$-ion) at $\mathrm{m} / \mathrm{z} 611.5$ (Figure $2 \mathrm{~d}$ and e) corresponding to the deletion of the $\mathrm{C}$-terminal $\varepsilon$-aminomethylated lysine amide (mass 173). These results suggest that the internal lysine deletion from the isometric octapeptides might be a consequence of the 


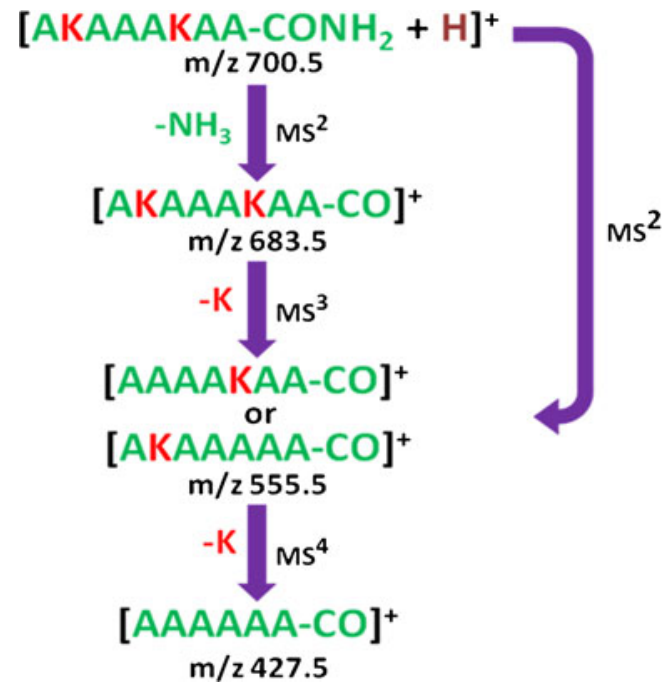

Scheme 2. Schematic representation of the internal lysine loss from the gaseous protonated peptide (C-terminal amidated) in the tandem mass spectrometric $\left(\mathrm{MS}^{n}\right)$ experiments

water-loss phenomenon discussed in previous section, and indeed involves the free $\varepsilon-\mathrm{NH}_{2}$ of the lysine residue.

Based on the above discussion, a mechanism involving formation of a cyclic imine intermediate leading to the deletion of the internal lysine from the collisionally activated protonated octapeptides has been proposed as shown in Scheme 3 (for a typical peptide AKAAAKAA$\mathrm{NH}_{2}$ ). Such seven member cyclic imine involving the lysine residue has been suggested to be formed by water loss from the peptide ion (Scheme S1B in the Supporting Information). Scheme 3 shows that the $b_{8}$-ion may exist in an oxazolone [15] structure with the charge (proton) delocalized on the whole peptide ion $[11,45]$. Protonation of the carbonyl oxygen of a lysine residue would enhance the electrophilicity of the amide carbon and allow formation of the seven membered cyclic intermediate $\mathbf{A}$ on nucleophilic attack of the amide carbon by the free $\varepsilon$ $\mathrm{NH}_{2}$ of the same lysine residue. The formation of analogous cyclic intermediates of larger size cannot also be ruled out, but such intermediates would not result in deletion of the internal lysine as shown in Scheme 3. Scheme 3 shows that the intermediate $\mathbf{A}$ can undergo cleavage in two possible pathways: Path I forms a $b_{n}$-ion ( $b_{6}$-ion, $\mathbf{B}$ in the typical peptide shown in Scheme 3 ), which contains a protonated cyclic amide ( $\varepsilon$-caprolactam) formed by the loss of a neutral peptide fragment $\left(\mathrm{AA}_{\mathrm{ox}}\right.$ in Scheme 3, 'ox' indicates C-terminal oxazolone form) from the $\mathrm{C}$-terminus in the intermediate $\mathbf{A}$. The protonated cyclic amide ( $\varepsilon$-caprolactam) has been shown to be more stable than the corresponding isomeric oxazolone structure [46, 48] of the $b_{n}$-ion containing lysine at the C-terminus. The other competitive pathway (path II) forms a cyclic imine intermediate (C) by the elimination of one $\mathrm{H}_{2} \mathrm{O}$ from the intermediate $\mathbf{A}$. This cyclic imine intermediate $(\mathbf{C})$ is the water-loss product of $b_{8}$-ion $\left(b_{8}-\mathrm{H}_{2} \mathrm{O}\right.$ ion $)$ as described in the previous section (neutral loss in Scheme S1 in the

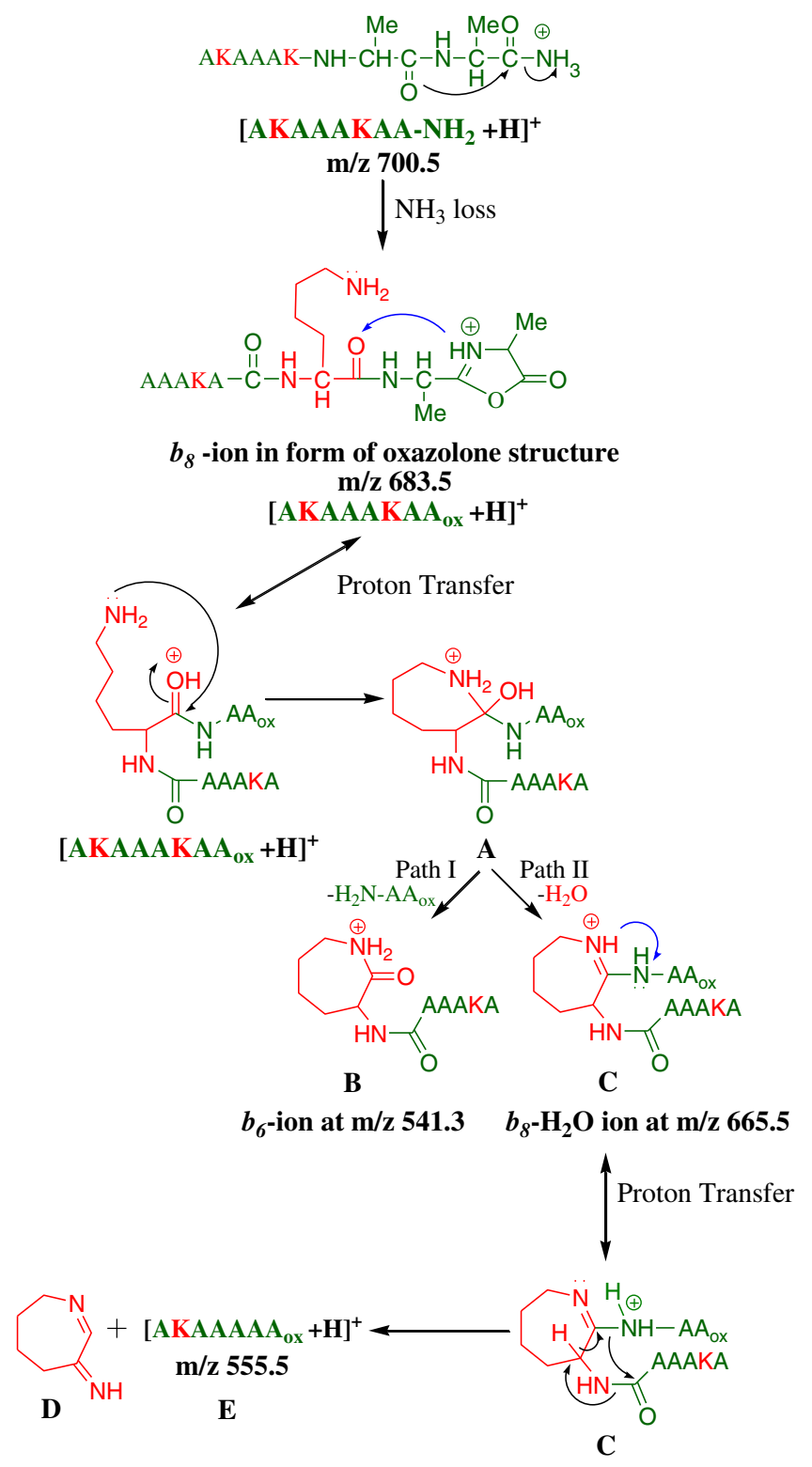

Scheme 3. The proposed mechanism of the deletion of the internal lysine residue from the gaseous protonated peptide upon collisional activation

Supporting Information). Scheme 3 shows that the species $\mathbf{C}$ is the precursor for the loss of internal lysine residue that is involved in the formation of the imine ring. A unimolecular bond rearrangement (Scheme 3) in the species $\mathbf{C}$ would lead to deletion of the neutral cyclic imine D (3,4,5,6-tetrahydro-2 H-azepin-6-imine, M.W. 110 ) forming the lysine deleted protonated peptide (species E). This scheme is further supported by the observation that the collisional activation of the species $\mathbf{C}$ $\left(b_{8}-\mathrm{H}_{2} \mathrm{O}\right.$ ion, $m / z$ 665.5) showed deletion of the cyclic imine (species D, M.W. 110) corresponding to loss of an internal lysine, and a neutral loss of water from the second lysine residue resulting in an ion at 537.5 (species $\mathbf{E}-\mathrm{H}_{2} \mathrm{O}$, see Figure $\mathrm{S} 6$ in the Supporting Information). The resulting peptide fragment $\left(\mathbf{E}-\mathrm{H}_{2} \mathrm{O}\right)$ is similar to the species $\mathbf{C}$ (with 
one lysine less than that in species C) and would subsequently release another cyclic imine (species D) leading to the deletion of the second lysine residue to form the protonated hexapeptide ion ([AAAAAA $\left.\mathrm{ox}+\mathrm{H}]^{+}\right)$. It is important to note that the species $\mathbf{B}\left(b_{\sigma}\right.$-ion, $\left.m / z 541.3\right)$, $\mathbf{C}$ $\left(b_{8}-\mathrm{H}_{2} \mathrm{O}\right.$ ion, $\mathrm{m} / z$ 665.5), and $\mathbf{E}(\mathrm{m} / z$ 555.5) shown in Scheme 3 have been detected and characterized by tandem mass spectrometry but the species $\mathbf{D}$, being neutral, could not be detected. The formation of a $b_{n}$-ion analogous to species A was also proposed earlier [46,48] to be involved in the formation of $\varepsilon$-caprolactam terminated peptide fragment ion (analogous to species B) as shown in Path I of Scheme 3.

\section{ESI-MS of Isotopically Labeled Octapeptides}

In order to achieve further insight into the gas-phase chemistry of the isomeric protonated octapeptides, one of the lysine residues of the peptide was labeled by ${ }^{15} \mathrm{~N}$ and ${ }^{13} \mathrm{C}$ isotopes. The electrospray ionization mass spectra of the isomeric octapeptide containing isotopically labeled lysine residue produced singly protonated species $\left[\mathrm{M}^{*}+\mathrm{H}\right]^{+}$at $\mathrm{m} / \mathrm{z}$ 708.5 and doubly protonated species $\left[\mathrm{M}^{*}+2 \mathrm{H}\right]^{+}$at $\mathrm{m} / \mathrm{z}$ 354.8 in the gas phase. Analogous to the unlabeled peptide (Figure 1), collisional activation (MS/MS) of the singly protonated isotopic peptide $\left[\mathrm{M}^{*}+\mathrm{H}\right]^{+}(\mathrm{m} / z$ 708.5) produced the characteristic $b_{n}$ and $y_{n}$ ions. Figure $5 \mathrm{a}$ shows the $\mathrm{MS}^{2}$ spectrum of the isotopically labeled peptide AKAAAK* $\mathrm{AA}-\mathrm{NH}_{2}$ (K* represents labeled lysine), which shows the ion signals at $\mathrm{m} / \mathrm{z} 555.5$ and $\mathrm{m} / \mathrm{z} 563.5$ (see the inset of Figure 5a) corresponding to the loss of $\mathrm{K}^{*}$ and $\mathrm{K}$ respectively from the $b_{8}$-ion of the labeled peptide. Furthermore, analogous to that observed in case of the unlabeled peptide (Figure 3), the $\mathrm{MS}^{3}$ on the $b_{8}$-ion of the labeled peptide resulted in enhanced loss of both $\mathrm{K}^{*}$ and $\mathrm{K}$ leading to increase in the relative abundance of both the ion signals at $\mathrm{m} / \mathrm{z} 555.5$ and $\mathrm{m} / \mathrm{z} 563.5$ (see Figure $5 \mathrm{~b}$ ). The tandem mass analyses $\left(\mathrm{MS}^{4}\right)$ showed that the ion signal at $\mathrm{m} / \mathrm{z} 555.5$ corresponds to the sequence AKAAAAA ox $_{\text {(Figure S8a in }}$ the Supporting Information), while the ion signal at $\mathrm{m} / \mathrm{z}$ 563.5 corresponds to the sequence AAAAK*AA ${ }_{\text {ox }}$ (Figure $\mathrm{S} 8 \mathrm{~b}$ in the Supporting Information). Moreover, collisional activation $\left(\mathrm{MS}^{4}\right)$ of both these ions produced the peptide fragment $\mathrm{AAAAAA}_{\text {ox }}$ by deletion of the remaining lysine residue as observed in case of the unlabeled analogues (Figure 4). These results unambiguiously support that collisional activation of the protonated octapeptide indeed leads to deletion of the internal lysine residue as proposed in the Scheme 3.

\section{Redesigning New Peptides to Get a General Insight of the Lysine Deletion Phenomena}

So far we have discussed the gas-phase fragmentation chemistry of the positional isomers of the peptide containing six alanine and two lysine residues. In order to assess whether the deletion of the internal lysine by collisional activation of the protonated peptide indeed applies to any lysine containing peptide or not,
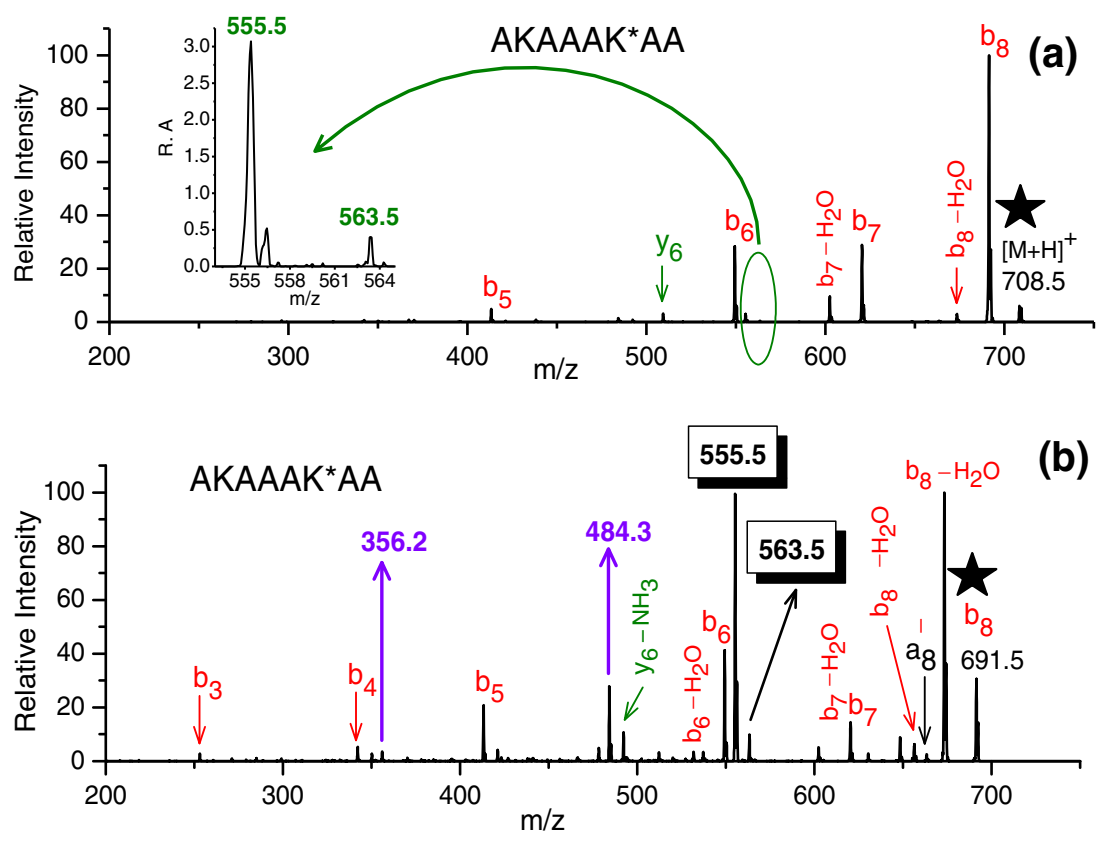

Figure 5. Low energy CID (a) $\mathrm{MS}^{2}$ spectrum of the singly protonated peptide AKAAAK ${ }^{\star} A A-\mathrm{NH}_{2}\left(\mathrm{~m} / z\right.$ 708.5), (b) $\mathrm{MS}^{3}$ spectrum of the $b_{8}$-ion, (c) $\mathrm{MS}^{4}$ spectrum of the fragment ion at $m / z 555.5$, and (d) $\mathrm{MS}^{4}$ spectrum of the fragment ion at $m / z 563.5$. The $\mathrm{K}^{*}$ in the peptide sequence indicates that this amino acid (lysine) is isotopically labeled $\left({ }^{13} \mathrm{C} \&{ }^{15} \mathrm{~N}\right)$. The inset of $(\mathbf{a})$ is the enlarged view of the $\mathrm{m} / \mathrm{z}$ range from 553 to 565 . For convenience the $\mathrm{y}$-ions have been labeled using green color, b-ions using red color, and other ions using black color in (a) and (b). Apart from the ions at $\mathrm{m} / \mathrm{z} 555.5$ and 563.5 the other nonsequence ion fragments, appeared due to the internal lysine deletion, have been shown using violet colored vertical arrow in (b) 
we investigated the gas-phase fragmentation chemistry of a new peptide of sequence YAKGFKL-NH $\mathrm{N}_{2}$. The amino acids containing carboxylic acid side chain (glutamic acid or aspartic acid) or guanidium side chain (arginine) were avoided in designing the peptide (YAKGFKL- $\mathrm{NH}_{2}$ ) as they have earlier been shown to introduce additional complexity in the tandem mass spectra [49].

The MS/MS spectrum (Figure 6a) of the singly protonated heptapeptide YAKGFKL-NH $\mathrm{N}_{2}$ (C-terminal amidated, $m / z$ 825.5) shows direct sequence ions ( $a_{n}, b_{n}$, and $y_{n}$-ions) along with their water-loss products. The number of water loss was directly correlated with the number of lysine residues in the fragment ions of this peptide, as observed in case of the isomeric octapeptides. The $\mathrm{MS}^{2}$ spectrum (Figure 6a) of the peptide also shows an intense ion signal at $\mathrm{m} / \mathrm{z} 680.3$ (25\% relative abundance in $\mathrm{MS}^{2}$ ) indicating the loss of $\sim 145 \mathrm{u}$ corresponding to the loss of a lysine residue and an ammonia molecule. This suggests that the deletion of internal lysine takes place from the $b_{7}$-ion of this heptapeptide. The tandem mass analyses $\left(\mathrm{MS}^{3}\right.$ ) suggested (Figure $6 \mathrm{~b}$ ) that the ionic species of $\mathrm{m} / \mathrm{z} 680.3$ indeed correspond to the loss of an internal lysine residue from the protonated heptapeptide, and have the sequence YAKGFL ${ }_{\text {ox }}$ or YAGF$\mathrm{KL}_{\mathrm{ox}}$ (ox refers to oxazolone). These fragment ions $(\mathrm{m} / \mathrm{z}$ 680.3) undergo further deletion of the remaining lysine residue to generate $\mathrm{YAGFL}_{\text {ox }}$ peptide fragment (Figure 6b) analogous to that observed in case of the isomeric octapeptides (Figure 4). These results thus suggest that the deletion of the internal lysine residue from the protonated peptide possibly does not depend on the sequence of the peptide.

\section{Lysine Deletion from Multiply Charged Peptides}

The doubly protonated peptide at $\mathrm{m} / \mathrm{z} 350.8$ observed in the mass spectra (Figure S1) of the isometric octapeptides, was mass selected and subjected to collision-induced dissociation. The $\mathrm{MS}^{2}$ spectra of the doubly protonated peptides (Figure S9 in the Supporting Information) show that the attachment of two protons provides dissociation pathways producing both singly charged as well as doubly charged fragment ions. All those spectra showed the appearance of a singly positive and a doubly positive ion respectively at $\mathrm{m} / \mathrm{z}$ 555.5 and $\mathrm{m} / z 278.3$ corresponding to the loss of an internal lysine residue followed by a neutral loss $\left(\mathrm{NH}_{3}\right)$ from the peptides. The $\mathrm{MS}^{2}$ of the doubly protonated heptapeptide $\left(\right.$ YAKGFKL-NH $\mathrm{N}_{2}$ ) also showed internal lysine deletion (Figure S10 in the Supporting Information) analogous to that observed in case of the singly protonated peptide (Figure 6). Thus, the deletion of the internal lysine residue is also possible by collisional activation of the multiply charged peptides.
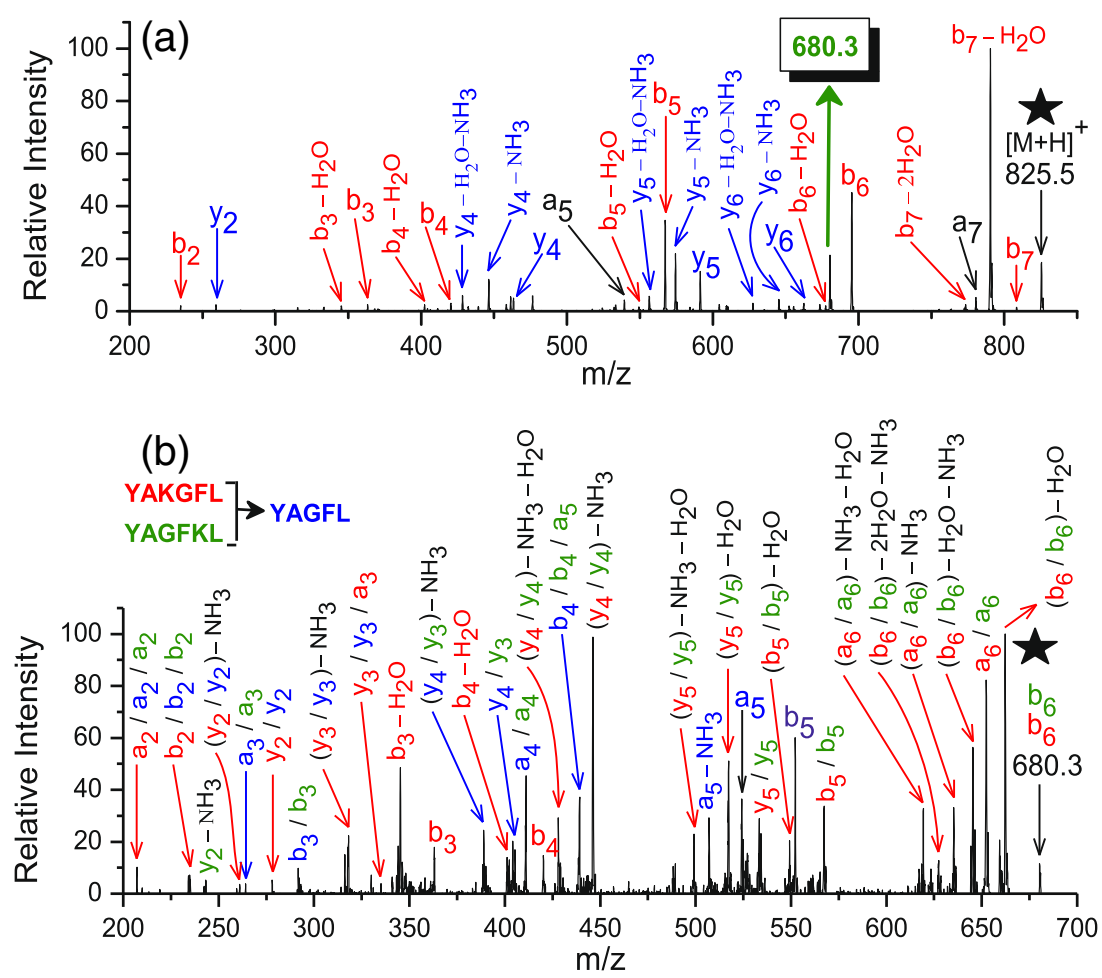

Figure 6. (a) Low energy CID-MS/MS $\left(\mathrm{MS}^{2}\right)$ spectrum of the singly protonated peptide YAKGFKL-NH $\mathrm{N}_{2}(\mathrm{~m} / z$ 825.5). For convenience, the $y$-ions have been labeled using blue color, b-ions using red color and other ions using black color. (b) CID$\mathrm{MS}^{3}$ spectrum of the ion at $\mathrm{m} / z 680.3$ derived from the $\mathrm{MS}^{2}$ of the same peptide. Here different colors have been used to label the fragment ions of the same colored amino acid sequence shown in top left corner. No ion signal was observed below $\mathrm{m} / \mathrm{z}$ 


\section{Conclusions}

The gas-phase collision-induced dissociation of a series of lysine containing synthetic peptides showed water-loss (neutral loss) from the sequence informative ions $\left(a_{n}, b_{n}\right.$, and $y_{n}$-ions). The number of water-loss was found to be equal to the number of lysine residues present in the corresponding fragment ions. The tandem mass spectrometry of the peptides, their aminomethylated derivatives, and the N-terminal acetylated derivatives showed that the gas-phase reaction between the side-chain amine of a lysine residue and the carbonyl group of the same residue results in the formation of a seven-membered cyclic imine fused to the backbone of the peptide fragment is involved in the water-loss mechanism.

As a consequence of this water-loss phenomenon, the peptide ion undergoes deletion of the internal lysine residue upon collisional activation by intramolecular bond rearrangement. The detailed mechanistic studies suggested that the deletion of the internal lysine takes place by a gas-phase degradation reaction of the cyclic imine containing peptide ion intermediate through releasing the corresponding cyclic imine from the interior of the peptide. The results have been confirmed by using isotopically labeled lysine residues and also by redesigning new peptide sequence, which suggest that the gas-phase deletion of the internal lysine on collisional activation of the peptide is possibly independent of the nature of the other residues in the peptide. This phenomenon may thus potentially have immense application in designing new proteomic methods for unambiguous identification of lysine residues in a protein or a peptide by mass spectrometry and further studies are in progress in our laboratory in this direction.

\section{Acknowledgment}

The authors thank Mr. Bharat T. Kansara for his help. Thanks also to Mr. C. Muralidharan and Mr. Bidyut Sarkar for their help during peptide synthesis. This work was supported by Tata Institute of Fundamental Research.

\section{Supporting Information Available}

Breakdown graphs, mass spectra of the peptides and their derivatives, and schematic representation of the peptide dehydration reactions are shown in the Supporting Information.

\section{References}

1. Reid, G.E., Shang, H., Hogan, J.M., Lee, G.U., McLuckey, S.A.: GasPhase Concentration, Purification, and Identification of Whole Proteins from Complex Mixtures. J. Am. Chem. Soc. 124(25), 7353-7362 (2002)

2. Pan, S., Aebersold, R., Chen, R., Rush, J., Goodlett, D.R., McIntosh, M.W., Zhang, J., Brentnall, T.A.: Mass Spectrometry Based Targeted Protein Quantification: Methods and Applications. J. Proteome Res. 8 (2), 787-797 (2008)

3. Demirev, P.A., Ramirez, J., Fenselau, C.: Tandem Mass Spectrometry of Intact Proteins for Characterization of Biomarkers from Bacillus Cereus T Spores. Anal. Chem. 73(23), 5725-5731 (2001)

4. Berna, M., Ackermann, B.: Increased Throughput for Low-Abundance Protein Biomarker Verification by Liquid Chromatography/Tandem Mass Spectrometry. Anal. Chem. 81(10), 3950-3956 (2009)
5. Sleno, L., Volmer, D.A.: Ion Activation Methods for Tandem Mass Spectrometry. J. Mass Spectrom. 39(10), 1091-1112 (2004)

6. McLuckey, S.A.: Principles of Collisional Activation in Analytical Mass Spectrometry. J. Am. Soc. Mass Spectrom. 3(6), 599-614 (1992)

7. Banerjee, S.; Mazumdar, S.: Electrospray Ionization Mass Spectrometry: A Technique to Access the Information beyond the Molecular Weight of the Analyte. Int. J. Anal. Chem. 2012((2012)

8. Hunt, D.F., Yates, J.R., Shabanowitz, J., Winston, S., Hauer, C.R.: Protein sequencing by tandem mass spectrometry. Proc. Natl. Acad. Sci. U.S.A. 83(17), 6233-6237 (1986)

9. Biemann, K.: Contributions of mass spectrometry to peptide and protein structure. Biol. Mass Spectrom. 16(1/12), 99-111 (1988)

10. Cole, R.B.: Electrospray and MALDI Mass Spectrometry, 2nd edn. John Wiley \& Sons, Inc., New Jersey (2010)

11. Boyd, R., Somogyi, A.: The mobile proton hypothesis in fragmentation of protonated peptides: a perspective. J. Am. Soc. Mass Spectrom. 21(8), 1275-1278 (2010)

12. Wysocki, V.H., Tsaprailis, G., Smith, L.L., Breci, L.A.: Mobile and localized protons: a framework for understanding peptide dissociation. J. Mass Spectrom. 35(12), 1399-1406 (2000)

13. Roepstorff, P., Fohlman, J.: Letter to the editors. Biol. Mass Spectrom. 11(11), 601-601 (1984)

14. Polfer, N.C., Oomens, J., Suhai, S., Paizs, B.: Spectroscopic and Theoretical Evidence for Oxazolone Ring Formation in CollisionInduced Dissociation of Peptides. J. Am. Chem. Soc 127(49), 1715417155 (2005)

15. Yalcin, T., Khouw, C., Csizmadia, I.G., Peterson, M.R., Harrison, A.G.: Why are B ions stable species in peptide spectra? J. Am. Soc. Mass Spectrom. 6(12), 1165-1174 (1995)

16. Chen, X., Steill, J., Oomens, J., Polfer, N.: Oxazolone versus macrocycle structures for leu-enkephalin b2-b4: Insights from infrared multiple-photon dissociation spectroscopy and gas-phase hydrogen/ deuterium exchange. J. Am. Soc. Mass Spectrom. 21(8), 1313-1321 (2010)

17. Ballard, K.D., Gaskell, S.J.: Sequential mass spectrometry applied to the study of the formation of "internal" fragment ions of protonated peptides. Int. J. Mass Spectrom. Ion Processes 111, 173-189 (1991)

18. Ambihapathy, K., Yalcin, T., Leung, H.W., Harrison, A.G.: Pathways to Immonium Ions in the Fragmentation of Protonated Peptides. J. Mass Spectrom. 32(2), 209-215 (1997)

19. Sun, S., Yu, C., Qiao, Y., Lin, Y., Dong, G., Liu, C., Zhang, J., Zhang, Z., Cai, J., Zhang, H., Bu, D.: Deriving the Probabilities of Water Loss and Ammonia Loss for Amino Acids from Tandem Mass Spectra. $J$. Proteome Res. 7(1), 202-208 (2007)

20. McClellan, J.E., Quarmby, S.T., Yost, R.A.: Parent and Neutral Loss Monitoring on a Quadrupole Ion Trap Mass Spectrometer: Screening of Acylcarnitines in Complex Mixtures. Anal. Chem. 74(22), 5799-5806 (2002)

21. Harrison, A.G., Young, A.B., Bleiholder, C., Suhai, S., Paizs, B.: Scrambling of Sequence Information in Collision-Induced Dissociation of Peptides. J. Am. Chem. Soc 128(32), 10364-10365 (2006)

22. Vachet, R.W., Bishop, B.M., Erickson, B.W., Glish, G.L.: Novel Peptide Dissociation: Gas-Phase Intramolecular Rearrangement of Internal Amino Acid Residues. J. Am. Chem. Soc. 119(24), 54815488 (1997)

23. Olsen, J.V., Mann, M.: Improved peptide identification in proteomics by two consecutive stages of mass spectrometric fragmentation. Proc. Natl. Acad. Sci. U.S.A. 101(37), 13417-13422 (2004)

24. Tang, X.J., Thibault, P., Boyd, R.K.: Fragmentation reactions of multiply-protonated peptides and implications for sequencing by tandem mass spectrometry with low-energy collision-induced dissociation. Anal. Chem. 65(20), 2824-2834 (1993)

25. Tang, X.J., Boyd, R.K.: Rearrangements of doubly charged acylium ions from lysyl and ornithyl peptides. Rapid Commun. Mass Spectrom. 8(9), 678-686 (1994)

26. Bythell, B.J., Maitre, P., Paizs, B.: Cyclization and Rearrangement Reactions of an Fragment Ions of Protonated Peptides. J. Am. Chem. Soc. 132(42), 14766-14779 (2010)

27. Bleiholder, C., Osburn, S., Williams, T.D., Suhai, S., Stipdonk, M.V., Harrison, A.G., Paizs, B.: Sequence-Scrambling Fragmentation Pathways of Protonated Peptides. J. Am. Chem. Soc. 130(52), 17774-17789 (2008)

28. Jia, C., Qi, W., He, Z.: Cyclization Reaction of Peptide Fragment Ions during Multistage Collisionally Activated Decomposition: An Inducement 
to Lose Internal Amino-Acid Residues. J. Am. Soc. Mass Spectrom. 18(4), 663-678 (2007)

29. Harrison, A.G.: Peptide Sequence Scrambling Through Cyclization of b5 Ions. J. Am. Soc. Mass Spectrom. 19(12), 1776-1780 (2008)

30. Molesworth, S., Osburn, S., Van Stipdonk, M.: Influence of Amino Acid Side Chains on Apparent Selective Opening of Cyclic b5 Ions. J. Am. Soc. Mass Spectrom. 21(6), 1028-1036 (2010)

31. Mouls, L., Aubagnac, J.-L., Martinez, J., Enjalbal, C.: Low Energy Peptide Fragmentations in an ESI-Q-Tof Type Mass Spectrometer. $J$. Proteome Res. 6(4), 1378-1391 (2007)

32. Yague, J., Paradela, A., Ramos, M., Ogueta, S., Marina, A., Barahona, F., de Lopez de Castro, J.A., Vazquez, J.: Peptide Rearrangement during Quadrupole Ion Trap Fragmentation: Added Complexity to MS/ MS Spectra. Anal. Chem 75(6), 1524-1535 (2003)

33. Saminathan, I.S., Wang, X.S., Guo, Y., Krakovska, O., Voisin, S., Hopkinson, A.C., Siu, K.W.M.: The Extent and Effects of Peptide Sequence Scrambling Via Formation of Macrocyclic b Ions in Model Proteins. J. Am. Soc. Mass Spectrom 21(12), 2085-2094 (2010)

34. Goloborodko, A., Gorshkov, M., Good, D., Zubarev, R.: Sequence Scrambling in Shotgun Proteomics is Negligible. J. Am. Soc. Mass Spectrom. 22(7), 1121-1124 (2011)

35. Harrison, A.G.: Cyclization of Peptide b9 Ions. J. Am. Soc. Mass Spectrom. 20(12), 2248-2253 (2009)

36. Chen, X., Yu, L., Steill, J.D., Oomens, J., Polfer, N.C.: Effect of Peptide Fragment Size on the Propensity of Cyclization in Collision-Induced Dissociation: Oligoglycine b2-b8. J. Am. Chem. Soc. 131(51), 1827218282 (2009)

37. Yu, L., Tan, Y., Tsai, Y., Goodlett, D.R., Polfer, N.C.: On the Relevance of Peptide Sequence Permutations in Shotgun Proteomics Studies. J. Proteome Res. 10(5), 2409-2416 (2011)

38. Banerjee, S., Mazumdar, S.: Non-covalent dimers of the lysine containing protonated peptide ions in gaseous state: electrospray ionization mass spectrometric study. J. Mass Spectrom. 45(10), 1212$1219(2010)$
39. Krusemark, C.J., Ferguson, J.T., Wenger, C.D., Kelleher, N.L., Belshaw, P.J.: Global Amine and Acid Functional Group Modification of Proteins. Anal. Chem. 80(3), 713-720 (2008)

40. Fenn, J.B., Mann, M., Meng, C.K., Wong, S.F., Whitehouse, C.M.: Electrospray ionization for mass spectrometry of large biomolecules. Science 246(4926), 64-71 (1989)

41. Prakash, H., Mazumdar, S.: Succinylation of cytochrome c investigated by electrospray ionization mass spectrometry: Reactive lysine residues. Int. J. Mass Spectrom. 281(1/2), 55-62 (2009)

42. Banerjee, S., Prakash, H., Mazumdar, S.: Evidence of Molecular Fragmentation inside the Charged Droplets Produced by Electrospray Process. J. Am. Soc. Mass Spectrom. 22(10), 1707-1717 (2011)

43. Prakash, H., Mazumdar, S.: Direct Correlation of the Crystal Structure of Proteins with the Maximum Positive and Negative Charge States of Gaseous Protein Ions Produced by Electrospray Ionization. J. Am. Soc. Mass Spectrom. 16(9), 1409-1421 (2005)

44. Jorgensen, T.J.D., Gardsvoll, H., Ploug, M., Roepstorff, P.: Intramolecular Migration of Amide Hydrogens in Protonated Peptides upon Collisional Activation. J. Am. Chem. Soc. 127(8), 2785-2793 (2005)

45. Dongre, A.R., Jones, J.L., Somogyi, A., Wysocki, V.H.: Influence of Peptide Composition, Gas-Phase Basicity, and Chemical Modification on Fragmentation Efficiency:Evidence for the Mobile Proton Model. $J$. Am. Chem. Soc. 118(35), 8365-8374 (1996)

46. Kish, M.M., Wesdemiotis, C.: Selective cleavage at internal lysine residues in protonated vs. metalated peptides. Int. J. Mass Spectrom. 227(1), 191-203 (2003)

47. Chen, X., Tirado, M., Steill, J.D., Oomens, J., Polfer, N.C.: Cyclic peptide as reference system for $\mathrm{b}$ ion structural analysis in the gas phase. J. Mass Spectrom. 46(10), 1011-1015 (2011)

48. Cordero, M.M., Houser, J.J., Wesdemiotis, C.: Neutral products formed during backbone fragmentations of protonated peptides in tandem mass spectrometry. Anal. Chem. 65(11), 1594-1601 (1993)

49. Paizs, B., Suhai, S.: Fragmentation pathways of protonated peptides. Mass Spectrom. Rev. 24(4), 508-548 (2005) 